books as to the properties exerted by the ingredients employed in the Gram method.

Investrgation shows that the Gram reaction follows the employrnent of the pararosanilin dyes, especially the violet dyes of this group, such as crystal violet, methyl violet, or mixtures of these known as gentian violet. The influence of the rodin is to form a new compound with the stained protoplasm of certain bacteria, which compound is insoluble or feebly soluble in alcohol. The alcohol serves as the decolorizing agent.

The exact difference in the chemical constitution between species of bacteria that stain positively and those that stain negatively by the Gram method is not definitely known, but the chemical constitution of the bacterial cell influences the behavior of the organism toward the Gram method.

Experiments along these lines are, still in progress.

The following new members were elected:

Professor Erastus G. Smith, Beloit College, Beloit, Wis.

Doctor Hideyo Noguchi, assistant, Rockefeller Institute, New York City.

Doctor Francis H. Slack, first assistant bacteriologist, Boston Board of Health Laboratory.

Doctor Eduardo Andrade, bacteriologist, State Board of Health, Jacksonville, Fla.

Doctor Howard T. Ricketts, instruetor in pathology, University of Chicago.

Doctor Gustav F. Ruediger, assistant, Memorial Institute for Infectious Diseases, Chicago, H.

Professor Wilfred H. Manwaring, Indiana University.

Professor Edwin G. Hastings, University of Wisconsin.

The officers for the ensuing year are:

President-E. F. Smith, Washington, D. C.

Vice-President-F. P. Gorham, Brown University.

Secretary-Treasurer-S. C. Prescott, Massachusetts Institute of Technology.

Council-E. O. Jordan, V. C. Vaughan, Simon Flexner, Joseph MeFarland.

- DelegatojtolAmerican Assomotion for therAd- vancement of Science-W. T. Sedgwick, Massachusetts Institute of Technology.

$$
\begin{aligned}
& \text { F. P. Gónhà, } \\
& \text { Secrétary. }
\end{aligned}
$$

\section{BROWN UNIVERSTTY.}

\section{THE BOTANICAL SOCIETTY OF AMERICA.}

THE twelfth annual meeting of the Botanical Society of America was held at New Orleans, in affiliation with the American Association for the Advancement of Science, from the first to the fourth of January, 1906. While the attendance, as in the case of the association, was not large, the meeting was a good one, and the program which follows contained papers of unusual interest.

As officers for the year $\mathbf{1 9 0 6}$ were elected, President, Professor F. S. Earle, Santiago de las Vegas, Cuba; Vicépresident, Professor F. E. Clements, Lincoln, Nebr.; Secretary, Professor William Trelease, St. Louis, Mo.; Treasurer, Dr. Arthur Holliek, Bronx Park, New York City. In addition to these officers and Past-president Harper, of Madison, Wisconsin, the council was completed by the election of Professor. B. L. Robinson, of Cambridge, Mass., and of Professor N. L. Brittion, of Bronx Park, New York City. Professor E. A. Burt and Dr. D. T. MacDougal were appointed to represent the society on the council of the American Association for the Advancement of Science. Drs. A. F. Blakeslee and G. H. Shull were elected to associate membership.

A vote of thanks was passed for the efficient service of the retiring secretary, Dr. MacDougal.

The treasurer's report showed a balance in the treasúry of $\$ 3,201.43$, of which a grant of $\$ 150.00$ was made to Dr. C. J. Chamberlain, of the University of Chicago, as an aid in a further field study of Dioon and in a morphological study of Ceratoza-, mia $y_{3}$ and a grant of $\$ 100.00$ to Professor J. 
C. Arthur for a continuation of his study of Uredineae.

As a result of long continued conferences between committees of the Botanical Society of America, the Society for Plant Morphology and Physiology and the American Mycological Society, and in connection with similar action on the part of the other bodies named, the society adopted a new constitution by which the three societies are federated under the name The Botanical Society of America, details of the federation under the new constitution being placed in the hands of the officers.

The following papers were presented:

J. C. ARTirur: 'Cultures of Uredineae in 1905.'

G. F. Atrinson: 'The Development of Ithyphallus impudicus (L.) Fries, from France.'

F. E. LLOYD: 'Some Physiological Aspects of Stomata.'

B. E. Livingston: 'Relative Transpiration.'

G. H. SHULL: 'Comparative Variation and Correlation in Three Mutants and their Parent.'

G. H. SHull: 'Some Latent Characters of the White Bean.'

D. T. MacDougal: ' Origin and Heredity of Bud Sports.'

D. T. MacDougaL: 'The Induction of Mutation by Artificial Stimulation.'

D. T. MacDougaL: 'New Mutants of the Evening Primrose.'

W. A. CANnon: 'Topography of the Chlorophyllapparatus of Some Desert Plants.'

D. S. Johnson: 'A New Type of Embryo-sac in Peperomia.'

E. 'C. Jeffrey and ARthur Hollick: ' Affinities of the Cretaceous Plant Remains referred to the Genera Dammara and Brachyphyllum.

B. J. Howard: 'The Tannin Cells of Persimmon.' (By invitation.)

V. M. Spalding: 'Some Problems in Desert Botany.' (By invitation.)

An interesting feature of the meeting was the exhibition of a large number of excellent photographs of European fleshy fungi, made by Professor Atkinson by the aid of a grant made at an earlier meeting of the society.

William Trelease, Secretaxy.

\section{THE ASSOCIATION OF AMERICAN GEOGRAPHERS.}

THE second annual meeting of the Association of American Geographers was held in New York City, December 26-27, 1905, under the presidency of Professor W. M. Davis, of Harvard University. The American Geographical Society generously offered the use of its house, at No. 15 West Eighty-first Street, and served luncheon to the members present on both days of the meeting. The annual dinner was held at the Hotel Endicott on the evening of December 26. It will appear from the program as given below that the several phases of geography, particularly the organic, physiographic and educational, were well represented. All the papers here named were read by their authors, and others were read by title. About forty members and invited speakers were present.

W. M. Davis, president's address: 'An Inductive Study of the Content of Geography.'

A. H. Brooks: "The Influence of Geography on the Exploration and Settlement of Alaska.'

J. Waster Fewres: 'The Sun's Influence on the Orientation of Hopi Pueblos.'

Martha Krug Genthe: 'Valley Towns of Connecticut.'

E. O. Hover: 'Geographical 'Notes on the Western Sierra Madre of Chihuahua.'

A. P. Brigham: 'Lake Loen (Norway) Landslip of January, 1905.'

Emory R. Johnson: 'Political Geography as a University Subject.'

Cyrus C. Adams: 'Map-making in the United States.'

Cleveland AbBe: 'A Modified Polar Projection Adapted to Dynamic Studies in Meteorology.'

IsAIAH BowMAN: "Hogarth's 'The Nearer East' in Regional Geography."

R. M. Brown: 'Notes on the Mississippi River Floods of 1903 and of Other Years.'

Henry G. BRyant: 'Notes on Some Results from a Drift Cask Experiment.'

N. M. Fenneman: 'An Example of Flood Plains produced without Floods.'

D. W. JoHnson: 'Map Studies for Engineering Students; the Classification of Contour Maps on a Physiographic Basis.' 